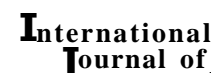

Journal of

Jysical

DOI : 10.15740/HAS/IJPE/10.1 and2/16-18

ducation

e ISSN-0976-7924 $\square$ Visit us : www.researchjournal.co.in

Research Paper

Volume 10 | Issue $1 \& 2$ | April \& October, 2017 | 16-18

\title{
Occupational stress among the male teachers of government senior secondary schools of Haryana
}

ISHWAR SINGH MALIK AND MEENU ${ }^{1}$

Received : 01.08.2017; Revised : 15.09.2017; Accepted : 24.09.2017

Members of the Research Forum

Associated Authors:

${ }^{1}$ Department of Physical Education,

Chaudhary Devilal University,

SIRSA (HARYANA) INDIA

Email: meenumanjeet88@gmail.com

Author for correspondence :

ISHWAR SINGH MALIK

Department of Physical Education,

Chaudhary Devilal University,

SIRSA (HARYANA) INDIA

Email: drishwarmalik@gmail.com

\section{-ABSTRACT}

The aim of the present study is to determine the occupational stress among the male teachers of government senior secondary schools of Haryana. To assess the statement of the problem total ninety teachers ( 30 science teachers, 30 math teachers and 30 physical education teachers) were selected for the study. Only male teachers who had working in government senior secondary schools of Haryana were selected. Occupational stress was measured by "Teachers occupational stress scale prepared by Dr. O. P. L. Srivastava and Dr. Bina Srivastava". To determine the level of significant difference descriptive study and to find out the group difference analysis of variance (ANOVA) was applied. The level of significance was fixed at .05 level.

- KEY WORDS : Occupational stress, Senior secondary school

- HOW TO CITE THIS PAPER : Malik, Ishwar Singh and Meenu (2017). Occupational stress among the male teachers of government senior secondary schools of Haryana. Internat. J. Phy. Edu., 10 (1\&2) : 16-18, DOI : 10.15740/HAS/IJPE/10.1and2/16-18. 